\title{
Impact Of Board Characteristics On Corporate Social Responsibility Disclosure
}

\author{
Muhammad Akram Naseem, Xi' an Jiaotong University, China \\ Salman Riaz, Xidian University, China \\ Ramiz Ur Rehman, University of Lahore, Pakistan \\ Amir Ikram, Xi'an Jiaotong University, China \\ Fizzah Malik, Xi'an Jiaotong University, China
}

\begin{abstract}
The purpose of this study is to explore the link between corporate governance characteristics and corporate social responsibility disclosure of listed companies in the Pakistan stock Exchange (PSX), Pakistan. A sample of 179 companies from financial and non-financial sectors are studied from 2009 to 2015. The data is collected from their annual reports and websites. Binary logistic regression analysis is employed to test the models. The results reveal that board size, number of meetings and board independence are significant corporate governance characteristics to establish the link with corporate social responsibility disclosure. This study also explore that the trend of CSR disclosure is increasing in financial as well as non-financial sector. Additionally, the companies disclose their CSR activities lead in financial performance as compare to their counterpart. This study adds in the literature to explore the influence of board characteristics on corporate social responsibility disclosure from a developing country's perspective.
\end{abstract}

Keywords: Board Characteristics; Corporate Governance; Corporate Social Responsibility; Logistic Regression

\section{INTRODUCTION}

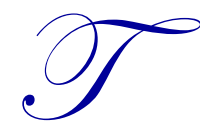
he literature of last fifty years or so depicted a mounting interest in corporate social responsibility (CSR), whereby firms are being held liable for any events affecting society and environment. From this perception, firms are observed as part of a larger economic system in which their actions might affect components of the system and consequently the system itself (Hawken, 1993; Rasmussen, 1997). Nowadays, society of any country play a vital role by putting stress on firms not to observe irresponsible measures towards the society and environment (Beltratti, 2005). As a result, firms nowadays used CSR to gain a competitive advantage. Further, companies involve in CSR may also want to obtain the benefits of such practices since CSR activities might have cost them a considerable amount of resources, which they may need to rationalize to their shareholders. Firms may then decide to disclose their CSR activities to inform their stakeholders.

Many corporations around the globe involve in CSR activities, some disclose their CSR activities in annual reports, and other publish it on their websites or issue separate CSR report. Cormier (2011) argued that the extra information of firm can bridge the gap between stakeholder and a firm and as a result affect the financial performance. Much of the prior empirical research based on CSR activities / disclosure and their impact on financial performance (Hart, 1994; Johnson \& Greening, 1994; Riahi-Belkaoui, 1992; Shihping \& Yang, 2014; Zhang, Zhang \& Seiler, 2015). However, much of the research focused on developed countries (Newson \& Deegan, 2002), whereas very few studies (Kuasirikun \& Sherer, 2004; Talha, Christopher \& Karthikeyani, 2016) concentrated on developing countries. Research on factors effecting CSR disclosure has mostly paid attention on the number of corporate characteristics such as company size (Simmons, 2016) and type of industry (Roberts, 1992). The link between corporate governance and CSR disclosure has been established through legitimacy and agency theory, but few studies test that link empirically (Hahn \& Kuhnen, 2013; Huafang \& Jianguo, 2007; Haniffa and Cooke, 2005). The legitimacy theory reveals that firms seek legitimacy through CSR disclosure which has its own strategic importance for them. 
Based on the legitimacy and agency theory, the purpose of this study is to explore the role of corporate governance on corporate social responsibility disclosure as well as to compare the financial performance of the listed companies in Pakistan Stock exchange on the basis of CSR disclosure within financial and non-financial sector. Additionally, to explore the trend of CSR disclosure between financial and non-financial sector. The descriptive analysis reveals that irrespective to sector, the overall trend to disclose CRS activities in listed companies of Pakistan is on increasing side from year to year. In comparison, on average, financial sector's CSR disclosure is more than non-financial sector. The rest of the article is ordered as follows: the next section provides an overview of literature and hypothesis development. After data and methodology empirical results and discussion is presented. Finally, last section provides the conclusions, limitations and suggestions for future research.

\section{LITERATURE REVIEW}

The agency theory is related to owner (principal)-manager (agent) relationship (Jensen \& Meckling, 1976), whereas agency problem and agency cost is considered as the conflict of interest between owner and manager of the business Board of directors appointed to avoid from agency problem and cost and to keep an eye on managers (Jensen \& Meckling, 1976) which also strengthen the internal control system and in a result managers' performance improved as well as the quality of CSR disclosure. states that society pressure on firms to conduct their activities in acceptable way is one of the cause to disclose CSR activities voluntarily.

Legitimacy theory (LT) is considered as the most thriving to explain voluntary disclosure as compare to competing theories (Islam \& Deegan, 2008). Newson and Deegan (2002) advocate that LT is the contract between firm and society like the principal - agent relationship to meet the societal expectations. LT expand the principal -agent relationship in favors of different stakeholders and this notion expand the functions of corporate governance. So, to maintain their claim on legitimacy managers are willing to disclose their CSR activities and other related information. Most of the research on CSR claimed that LT is the main driver for companies to disclose CSR in their audited annual reports (Cormier \& Magnan, 2015; Woodward, Edwards \& Birkin, 1996). LT emphasize the significance of societal acceptance in ensuring a company's long term survival. In literature the studies related to factors influencing CSR disclosure found that firm size and industry type were statistically significant in explanation of CSR disclosure (Talha et al., 2016). Significance of firm size and industry type might be explained by LT. Though, LT was insufficient to explain the variation in findings due to country of origin. Ashforth and Gibbs (1990) argued that legitimacy is deemed problematic as societal expectations varies with time and uncertain, furthermore it's tough to recognize the principal to whom the agent is answerable (Woodward et al., 1996). Hence, this study is based on agency theory and legitimacy theory to explore the link between corporate governance characteristics and CSR disclosure.

\subsection{Hypothesis Development}

\subsubsection{Board Size}

Existing literature on board size can be classified into two categories. One is in favor of large boards whereas other advocate smaller boards. The advocates of larger boards believed that large boards are inefficient as they are week in control of management and increase the agency cost. However, this notion is defying by stating that larger boards may less influenced by management. Small boards are deemed efficient but they may have influenced by managers. Moreover, it is observed that large boards are diverse with reference to the education, expertise and gender of directors (Laksmana, 2008). Various studies have reported a positive relationship between CSR disclosure and board size (Ntim \& Soobaroyen, 2013; Esa, Anum, \& Gazali, 2012). Therefore, it is hypothesized that:

H1: There is a positive association between board size and CSR disclosure

\subsubsection{Board Meetings}

The number of meetings of board members in a year is used as one of the indicator of corporate governance (Laksmana, 2008), and also reflect the effectiveness of board and the level of control on delivered activities (Vafeas, 1999; Laksmana, 2008). Laksmana (2008) states that regular numbers of meetings give them chance to share more 
information and improved decision making, ultimately increased firm value. However, the diverse notion is that the board spent less time of directors which does not reflect in significant exchange of views among them (Lipton \& Lorsch, 1992; Vafeas, 1999). In literature, less attention is given to frequency of board meetings to explore CSR disclosure. However, Giannaraki (2014) reported a positive association between number of meetings and CSR disclosure. Boards with large number of meetings likely to handle business operations and disclosure of CSR information to satisfy different stakeholders in an effective way. Therefore, in the present study, it is hypothesized:

H2: There is a positive relationship between the number of board meetings and the extent of CSR disclosure.

\subsubsection{Executive Directors in the Board (Board Independence)}

Board independence is another significant feature of corporate governance. Advocates of the agency theory propose that independent directors in board may avoid from agency problems and in result board monitoring quality enrich (Jensen \& Meckling, 1976). Independent directors wield stress on managers to disclose more information and avoid agency costs. The literature has mixed results on the association of board independence and CSR disclosure. Number of studies reported negative association between CSR disclosure and board independence (Haniffa \& Cooke, 2005) whereas, Barako \& Brown (2008) reported a positive relationship between board independence and CSR disclosures. Based on the above arguments the following hypothesis is proposed:

H3: There is a positive association between board independence and CSR disclosure.

\subsubsection{Gender Diversity in Board (021)}

Gender diversity as one of the aspect of board diversity gained a significant importance in corporate governance literature, and advocates of diversity argued that diverse boards may have better understanding of complex issues as compared to homogenous boards Carter, Simkins, \& Simpson, 2003). Moreover, it was found that female entrepreneurs play a pivotal role in the emerging economy of Pakistan (Ikram, Su, Fiaz, \& Shabbir, 2016), thus it is imperative to take this dimension into consideration. Proportion of females in the board used as a proxy of gender diversity as well as board diversity (Carter et al., 2003). No satisfactory support exist related to CSR disclosure and gender diversity in the board. Daily and Dalton (2003) and Zhang, Zhu \& Ding, (2013) suggest that the presence of females in the board of directors may compel the board to meet the stakeholders expectations, thus the execution of CSR and its disclosure is more viable. Thus, the number of females in the boards is significantly different with respect to the involvement of companies in CSR (Webb, 2004), whereas, Khan (2010) reported no association between CSR disclosure and female representation on the board of directors. Thus, based on the above studies, the hypothesis is stated as:

H4: There is a positive association between number of women on board and CSR disclosure.

\section{DATA AND METHODOLOGY}

\subsection{Sample and Data}

The stratified sample is selected at two stages, at first stage seven sectors are selected and on $2^{\text {nd }}$ stage companies are selected randomly from selected sectors, total selected companies are 179 from 903 companies listed in Pakistan Stock Exchange (PSX). The annual data of selected companies collected from 2009 to 2015 . The overall year -firm observations are 1253. Table 1 represent the number of companies selected for the data collection. Data related to boards characteristics as well as financial information collected and compiled from the audited published annual reports of the selected companies. The companies disclose their CSR information differently, some of them use their web site for CSR disclosure, while some disclose in their annual reports and some prefer to publish CSR reports separately. So, all the above stated sources were used to get information about selected companies CSR disclosure. 
Table 1. Sample Distribution

\begin{tabular}{|c|c|}
\hline Sector & No. of companies \\
\hline Banking & 25 \\
\hline Insurance & 6 \\
\hline Cement & 20 \\
\hline Fuel \& Energy & 20 \\
\hline Sugar & 23 \\
\hline Textile & 85 \\
\hline Total & 179 \\
\hline
\end{tabular}

\subsection{Measurement of variables}

The dependent variable, CSR disclosure was formed as binary variable. A firm that disclose their CSR activities was allotted " 1 " whereas " 0 " is allotted to firm which does not disclose their CSR. The explanatory variables of the study were board size, board meeting during a year, board independence and gender diversity in the board. Financial variables are taken as control variables. Operationalization of the dependent, explanatory and control variables are in Table 2.

Table 2. Description of variables

\begin{tabular}{l|l}
\hline \multicolumn{1}{c}{ Dependent Variable } & \multicolumn{1}{c}{ Operationalization } \\
Corporate Social Responsibility Disclosure (CSRD) & Firm disclose their CSR activities $=1$ \\
\hline $\begin{array}{l}\text { Explanatory Variables } \\
\text { Board Size (BS) }\end{array}$ & Firm does not disclose CSR activities $=0$ \\
\hline Board Meetings (BM) & Total number of directors in the board \\
\hline Board Independence (BI) & Number of meetings of board members in a year \\
\hline Gender Diversity (GD) & Proportion of independent directors \\
\hline Control Variables & Proportion of female directors in the board \\
\hline Total assets (LTA) & \\
\hline Shares (LSH) & Natural log of total assets \\
\hline ROE & Natural log of total number of shares \\
\hline DPS & Return on equity \\
\hline Tobin q & Dividend per share \\
\hline
\end{tabular}

\subsection{Method of Analysis}

To test the stated hypothesis, binary logistic regression analysis was employed which developed by David Cox (1958), which helps us to estimate the odds of a binary outcome variable on the basis of one or more explanatory variables which can be categorical or quantitative like other forms of regression models. Considering the difference between classical linear regression model (CLRM) and logistic regression model, the assumptions of CLRM are no longer valid for binary logistic regression model in particular, errors cannot follow normal distribution. To execute binary logistic regression, first control variables were tested and then along with explanatory variables full logistic regression model executed. Peng, So, Stage, and St John, (2002) suggest that minimum number of observations for logistic regression analysis should be 100, so 1253 observations are quite adequate for this study.

Accordingly, two logistic regression models are as under:

Model 1:

$$
\begin{aligned}
\operatorname{Logit}[P(C S R D)]= & \ln \{P(C S R D) /[1-P(C S R D)]\} \\
= & \alpha+\beta_{1} L T A+\beta_{2} L S H+\beta_{3} R O E+\beta_{4} D P S+\beta_{5} T O B I N Q
\end{aligned}
$$


Model 2:

$$
\begin{aligned}
& \operatorname{Logit}[P(C S R D)]=\ln \left\{\frac{P(C S R D)}{[1-P(C S R D)]}\right\}=\alpha+\beta_{1} B S+\beta_{2} B M+\beta_{3} B I+\beta_{4} G D+\beta_{5} L T A+\beta_{6} L S H+ \\
& \beta_{7} R O E+\beta_{8} D P S+\beta_{9} T O B I N Q
\end{aligned}
$$

4. RESULTS AND DISCUSSION

\subsection{Descriptive Statistics}

Graph 1, depicts that there is an increasing trend between financial and non-financial sectors from 2009 to 2015 to disclose their corporate social responsibility activities. On average $30 \%$ of the selected companies of non-financial sector disclose their CSR activities over the selected time period whereas in financial sector the proportion is $49 \%$. To compare the financial performance of companies within financial and non-financial sector with reference to CSR disclosure, year wise independent sample t-test is applied. Table 3 describe that, in non-financial sector in every year the total number of shares differ significantly between the companies involve in CSR disclosure or not, implies that the companies involve in CSR disclosure perform better than those not involve in CSR disclosure In financial sector the difference of number of shares significant from 2011 to 2015, indicates the companies involve in CSR disclosure perform better.

Table 3. T-test to compare the performance with respect to CSR Disclosure

\begin{tabular}{l|c|c|c|c}
\hline & \multicolumn{2}{|c}{ Financial Sector } & \multicolumn{2}{c}{ Non-Financial Sector } \\
\hline \multicolumn{1}{c|}{ Year } & t-stat & Sig & t-stat & sig \\
\hline 2009 & -1.32 & 0.20 & -1.86 & 0.07 \\
\hline 2010 & -1.29 & 0.21 & -3.69 & 0.00 \\
\hline 2011 & -1.82 & 0.08 & -3.44 & 0.00 \\
\hline 2012 & -2.11 & 0.05 & -4.41 & 0.00 \\
\hline 2013 & -0.69 & 0.50 & -3.29 & 0.00 \\
\hline 2014 & -2.26 & 0.03 & -2.98 & 0.00 \\
\hline 2015 & -2.49 & 0.02 & -2.44 & 0.02 \\
\hline
\end{tabular}

Table 4 and 5 describe the descriptive statistics in form of minimum, maximum, average and variation of the data and spearman correlation coefficients of the variables involved in this study respectfully. The dependent variable corporate social responsibility disclosure (CSRD) has a mean of 0.39 suggested that $39 \%$ of the sample companies over the selected time period disclose their CSR activities. The board size ranges from 4 to 15 whereas the average board size is 7.89 which is consistent with the board size reported in various studies of Asia and Africa (Esa et al. 2012; Barako et al., 2008). The average number of meeting of the board members held in a year is 1.05 and maximum number of meeting held in a year does not exceed from two. Number of independent directors in the board is used as the indicator of board independence which varies from 0 to 7 whereas the average number of independent directors is 1.84 indicates in average 2 members of the board are observed independent which is in line for firms in Asian economies. Proportion of female directors in the board is used as in indicator of gender diversity which ranges from $13 \%$ to $43 \%$ and the average 0.26 indicate that $26 \%$ of the directors in the boards of listed companies of Pakistan Stock exchange are females. Similarly, the descriptive statistics of the financial indicators are given in Table 4. 
Graph 1. Percent of Companies involve in CSR disclosure between Financial and Non Financial Sector

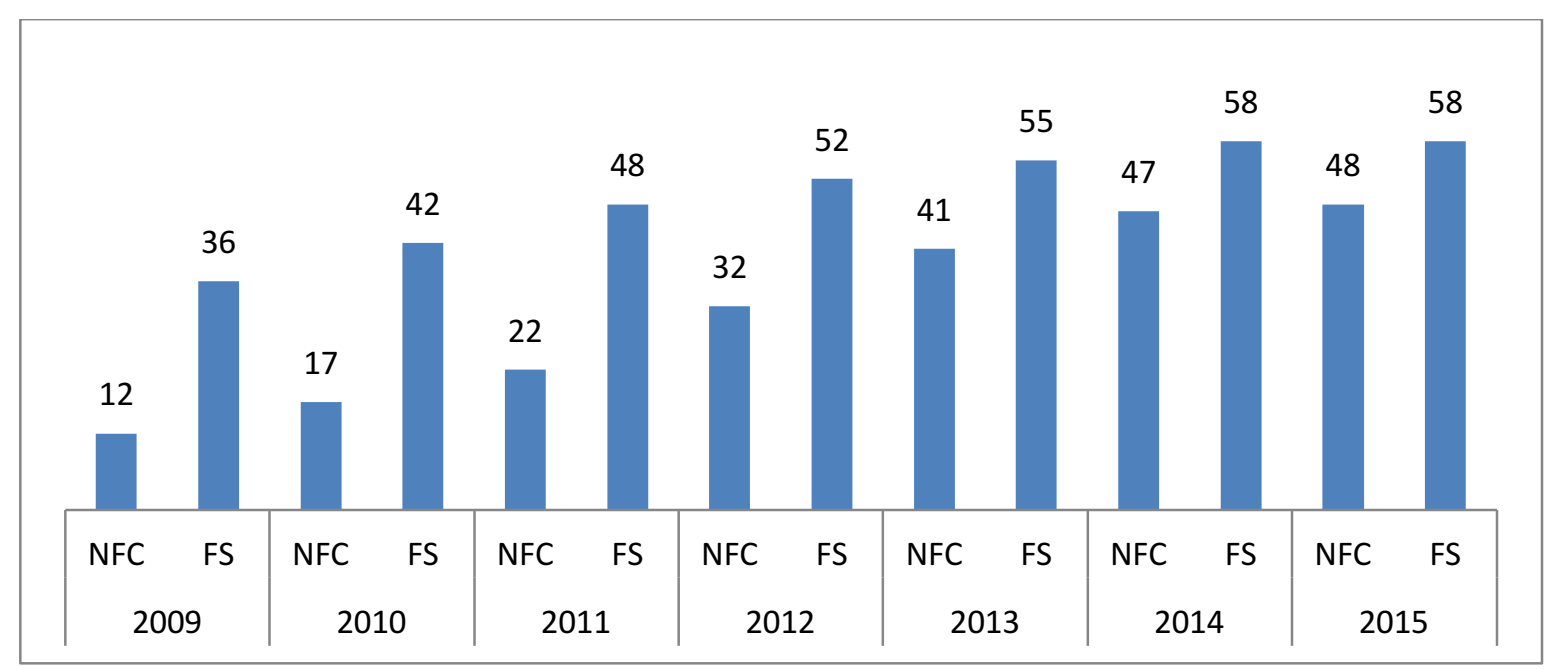

Table 4. Descriptive Statistics

\begin{tabular}{|c|c|c|c|c|}
\hline & Min & Max & Mean & Std. Dev \\
\hline Corporate Social Responsibility (CSRD) & 0 & 1 & .39 & .49 \\
\hline Board Size (BS) & 4 & 15 & 7.89 & 1.41 \\
\hline Board Meetings(BM) & 1 & 2 & 1.05 & .23 \\
\hline Board Independence (BI) & 0 & 7 & 1.84 & 1.41 \\
\hline Proportion of female directors (GD) & .13 & .43 & .26 & .11 \\
\hline Log of Total Assets (LTA) & 9.19 & 20.02 & 15.37 & 1.69 \\
\hline Log of Total number of Shares (LSHARES) & 6.21 & 17.13 & 10.89 & 2.01 \\
\hline Return on Equity (ROE) & -319 & 94 & -.12 & 9.99 \\
\hline Dividend Per Share (DPS) & 0 & 171 & 3.86 & 10.48 \\
\hline Tobin's q & 0 & 526 & 5.01 & 32.32 \\
\hline
\end{tabular}

Table 5 present the spearman correlation coefficient between the variables involved in this study. The outcome variable, corporate social responsibility disclosure (CSRD) is positively associated with board size and board meetings and the association between proportion of female directors and corporate social disclosure is insignificant. Among the financial indicators, the indicators of size, total assets and number of shares, are positively associated with corporate social responsibility disclosure, indicator of market value, Tobin's Q is also positively associated with corporate social responsibility disclosure at $1 \%$ level of significance.

Furthermore, corporate board's characteristics are negatively correlated as board size is negatively and statistically associated with board independence and proportion of female directors at $1 \%$ level of significance. Board meetings and board independence is observed to be positively associated and statistically significant. Similarly, the bivariate associations between financial variables, which are used as control variables, are found to be positively and statistically significant at $1 \%$ level of significance. Moreover, the strength of association between different variables indicates that multicollinearity can't affect the regression results. 
Table 5. Correlation Co-efficient

\begin{tabular}{|c|c|c|c|c|c|}
\hline & Board Size & Board Meetings & $\begin{array}{c}\text { Board } \\
\text { Independence }\end{array}$ & $\begin{array}{l}\text { Prop. of Female } \\
\text { Directors }\end{array}$ & LTA \\
\hline Board Size & 1.00 & & & & \\
\hline Board Meetings & -0.02 & 1.00 & & & \\
\hline Board Independence & $-.100^{* *}$ & $.109^{* *}$ & 1.00 & & \\
\hline Proportion of female directors & $.492^{* *}$ & 0.09 & -0.08 & 1.00 & \\
\hline LTA & $.218^{* *}$ & $.150^{* *}$ & $-.155^{* *}$ & 0.01 & 1.00 \\
\hline Return on Equity & 0.04 & 0.01 & -0.03 & -0.10 & $.144^{* *}$ \\
\hline Dividend Per Share & $.093^{*}$ & $.159^{* *}$ & -0.01 & 0.03 & $.474^{* *}$ \\
\hline Tobin's q & $.111^{* *}$ & $.084^{*}$ & $-.122^{* *}$ & -0.10 & $.255^{* *}$ \\
\hline Corporate Social Responsibility & $.260^{* *}$ & $.155^{* *}$ & $0.03 * *$ & .417 & $.200^{* *}$ \\
\hline
\end{tabular}

\begin{tabular}{l|c|c|c|c|}
\hline & L SHARES & $\begin{array}{c}\text { Return on } \\
\text { Equity }\end{array}$ & $\begin{array}{c}\text { Dividend Per } \\
\text { Share }\end{array}$ & Tobin's q \\
\hline LSHARES & 1.00 & & \\
\hline Return on Equity & 0.02 & 1.00 & \\
\hline Dividend Per Share & $.155^{* *}$ & $.403^{* *}$ & 1.00 & \\
\hline Tobin's q & $.298^{* *}$ & $.092^{* *}$ & $.465^{* *}$ & 1.00 \\
\hline Corporate Social Responsibility & $.276^{* *}$ & 0.05 & 0.06 & $.147^{* *}$ \\
\hline
\end{tabular}

Note: **, ${ }^{*}$ Significant at the 0.01 and 0.05 levels, respectively

\subsection{Logistic Regression Results}

Prior to logistic regression analysis, for robustness of the analysis, the tests of linearity, multicollinearity and outliers were performed. To test the linearity between logit and continuous explanatory variables, Box-Tidwell transformation is applied, results showed that total assets and number of shares were significant $(p<0.01)$. Natural logarithm transformation applied on total assets and number of shares to validate the linearity. In Table 4, all the correlation coefficient among variables in the study are less than the critical level of 0.8 which suggest that there is no problem of multicollinearity (Gujarati, 1988; Hair, Anderson, Tatham \& Black 1995). To observe the outlier affect, Studentized residuals, deviance and Cook's distance (D) were performed and it was observed that model was not influenced by extreme values.

Table 6 presents the statistics of the goodness of model and the explanatory power of the model. Model I based on financial variables, which are used as control variables of the study. In model I, chi-square statistics suggest that sample data describe the purposed model. The pseudo co-efficient of determination are measured by Cox-Snell and Nagelkerke, which are in acceptable limits. The predictive accuracy of Model I was $71.5 \%$ which describe the significance of the financial indicators of the firm to explain the firm's Corporate social responsibility disclosure. Model II based on corporate governance characteristics and control variables and the value of chi-square and significance values suggest that sample data describe Model II. Additionally, the Cox \& Snell R Square is $34 \%$ and Nagelkerke R Square is 52\%. The overall predictive accuracy of Model II is 84.4.

Table 6. Logistic Regression fit statistics

\begin{tabular}{l|rr}
\hline & Model I & Model II \\
\hline Omnibus Tests of Model Coefficients & & $18.472 / 0.018$ \\
\hline Chi-square / Sig & $88.443 / 0.000$ & 29.201 \\
\hline-2 Log likelihood & 847.770 & 0.34 \\
\hline Cox \& Snell R Square & 0.12 & 0.52 \\
\hline Nagelkerke R Square & 0.16 & 84.4 \\
\hline Predictive accuracy & 71.5 & \\
\hline
\end{tabular}


Table 7 represents the results of logistic regression results in form of co-efficient (B), standard error (S.E), wald statistic (Wald), significance (Sig.) and odds ratio (Exp(B)). In model I, the impact of log of total number of shares and Tobin'q are positive and significantly associated with CSR disclosure as significance value less than $1 \%$, whereas DPS is significant at $10 \%$ level. The likelihood of CSR disclosure increases 1.414 times as the $\log$ of number of shares increase by one point, similarly the probability of CSR disclosure increases 1.006 times as the Tobin Q increases one point.

Table 7. Logistic regression model results

\begin{tabular}{|c|c|c|c|c|c|}
\hline & B & S.E. & Wald & Sig. & $\operatorname{Exp}(B)$ \\
\hline \multicolumn{6}{|l|}{ Model I } \\
\hline LTA & -.098 & .060 & 2.669 & .102 & .907 \\
\hline LSHARES $^{* * *}$ & .346 & .051 & 45.615 & .000 & 1.414 \\
\hline ROE & .017 & .015 & 1.237 & .266 & 1.017 \\
\hline DPS $^{*}$ & .011 & .007 & 2.923 & .087 & 1.011 \\
\hline Tobinq $^{* * *}$ & .006 & .002 & 8.157 & .004 & 1.006 \\
\hline Constant & -2.833 & .624 & 20.616 & .000 & .059 \\
\hline \multicolumn{6}{|l|}{ Model II } \\
\hline LTA & -.139 & .096 & 2.120 & .145 & .870 \\
\hline LSHARES $^{* * *}$ & .314 & .077 & 16.615 & .000 & 1.368 \\
\hline ROE & .017 & .015 & 1.191 & .275 & 1.017 \\
\hline DPS & .010 & .011 & .780 & .377 & 1.010 \\
\hline Tobinq $^{* *}$ & .006 & .003 & 5.575 & .018 & 1.006 \\
\hline $\mathrm{BS}^{* * *}$ & .373 & .091 & 16.984 & .000 & 1.452 \\
\hline $\mathrm{BM}^{* * *}$ & 1.186 & .323 & 13.508 & .000 & 3.274 \\
\hline $\mathrm{BED}^{* *}$ & .111 & .053 & 4.375 & .036 & 1.118 \\
\hline GD & .100 & 1.136 & .008 & .930 & 1.105 \\
\hline Constant & -6.248 & .900 & 48.199 & .000 & .002 \\
\hline
\end{tabular}

From the results of model II, among corporate governance characteristics the Wald statistic of Board size, Board meetings and Board independence are positive as well as significant at $1 \%$ and $5 \%$ level, which support the earlier stated hypothesis 1, 2 and 3.whereas, the proportion of female directors in the board was found to be insignificant and the findings does not support hypothesis 4 . The positive coefficient of board size describe that larger boards may influence the CSR disclosure policy and the odds of CSR disclosure increased 1.452 times as board size increases by one member. The likelihood of CSR disclosure increases 3.274 times as number of meetings of the board members increase by one point, similarly, the probability of CSR disclosure increases as the proportion of independent directors increases one point.

\section{CONCLUSION AND RECOMMENDATIONS FOR FUTURE RESEARCH}

From agency and legitimacy theories background, this research explores the impact of corporate governance characteristics on corporate social responsibility disclosure. To test the hypothesis of this study, a sample of 179 companies listed in Pakistan stock exchanges (PSE) from seven different sectors are observed from 2009 to 2015.The findings of the study based on binary logistic regression analysis showed that board size, board meetings and board independence has a positive link towards corporate social responsibility disclosure, whereas proportion of female directors in the board has insignificant impact on corporate social disclosure (CSRD). In Pakistan female's participation in boards not like the developing countries, which also reflect the dominance of male members in boards of selected companies, mostly female directors act as latent members of the board.

Empirical findings support the literature related to accepted hypothesis, though theoretical link between corporate governance characteristics and corporate social responsibility disclosure is still week, especially in developing country context. The findings also favor the literature that firm size has a significant impact on corporate social responsibility disclosure, as number of shares increases the likelihood of corporate social responsibility disclosure increases to avoid agency problems. Additionally, the indicator of market reputation, Tobin'q is positively and significantly linked with corporate social responsibility disclosure. 
This study has few implications to the CSR literature. This study adds in the literature from CSR disclosure perspective and especially in developing country's context. Additionally, it should be acknowledged that listed companies in Pakistan voluntary commence corporate social disclosure in lack of bindings of CSR disclosure from regulatory agencies as the notion of CSR disclosure is somewhat new for corporate managers. From practical implications perspective, findings reveal that large boards, number of meetings and board independence are likely to predict CSR disclosure, however from resource dependence perspective only large firms can afford the luxury of large boards. Large boards have their own consequences as the association of board size with number of meetings and board independence are negative.

Findings of this research are not free from few limitations. The dependent variable is a binary variable which does not indicate the quality and extent of CSR disclosure. Consequently, non-disclosure of CSR does not reflect the company's non-involvement in CSR activities. The sample is taken from only one country and the results can be further validate to include the data of other countries. Considering the limitations of this research, Future research need to study the impact of board characteristics on the quality and extent of CSR disclosure, furthermore the impact of ownership structure on quality and extent of CSR disclosure may enrich the CSR literature. The topic can be further explored from CEO profiles perspective and mixed research methodology may help to get more insights of CSR related studies. There is also a need to explore the topic from small medium enterprise (SME) perspective.

\section{AUTHOR BIOGRAPHIES}

Muhammad Akram Naseem is pursuing his $\mathrm{PhD}$ in Financial Management from School of Management, Xi'an Jiaotong University, China. He is also serving as Assistant Professor (currently on study leave) in Lahore Business School, The University of Lahore, Pakistan. His field of interest is applied statistics, corporate social responsibility, and financial management. Iqra4ever@hotmail.com (Corresponding author)

Salman Riaz is PhD Scholar at Xidian University, China. He has extensive professional experience in the accounts and finance department of reputed academic institutions of Pakistan. His research interest includes accounting, corporate finance, behavioral finance and investment. grtslmn@hotmail.com

Dr. Ramiz Ur Rehman is serving as an Assistant Professor of finance at Lahore Business School, The University of Lahore. He has more than ten years of teaching and research experience at the university level. His interests lie in financial management, business ethics and corporate governance. Ramiz_rehman@hotmail.com

Amir Ikram is PhD student at School of Management, Xi'an Jiaotong University, China. Besides publishing articles in international journals and conference proceedings, he has contributed to numerous projects of 'National Natural Science Foundation of China'. His academic resources can be accessed from www.amirikram12.blogspot.com. Email: Amirikram12@hotmail.com

Fizzah Malik is doing her PhD in Financial Management from School of Management, Xi'an Jiaotong University, China. Her area of research includes corporate finance, behavioral finance and corporate social responsibility.

\section{REFERENCES}

Ashforth, B.E., \& Gibbs, B.W. (1990). The double-edge of organizational legitimation. Organization Science, 1(2), $177-194$.

Barako, D. G., \& Brown, A. M. (2008). Corporate social reporting and board representation: Evidence from the Kenyan banking sector. Journal of Management and Governance, 12(4), 309-324.

Beltratti, A. (2005). The complementarity between corporate governance and corporate social responsibility. The Geneva Papers on Risk and Insurances, 30(3), 373-86.

Carter, D. A., Simkins, B. J., \& Simpson, W. G. (2003). Corporate governance, board diversity, and firm value. Financial Review, 38(1), 33-53.

Cormier, D., \& Magnan, M. (2015). The economic relevance of environmental disclosure and its impact on corporate legitimacy: An empirical investigation. Business Strategy and the Environment, 24(6), 431-450.

Cormier, D. (2011). The Informational Contribution of Social and Environmental disclosures for Inverstors. Management Decision, 49(8), 1276-1304.

Cox, D. (1958). The regression analysis of binary sequences (with discussion). J Roy Stat Soc B, 20, $215-242$. 
Daily, C.M., \& Dalton, D.R. (2003). Women in the boardroom: a business imperative. Journal of Business Strategy, $24(5)$, 8-9.

Esa, E., Anum, N., \& Gazali, M. (2012). Corporate social responsibility and corporate governance in Malaysian governmentlinked companies. Corporate Governance, 12(3), 292-305.

Giannarakis G. (2014). Corporate governance and financial characteristic effects on the extent of corporate social responsibility disclosure. Social Responsibility Journal, 10(4,)569 -590.

Gujarati, D. (1988). Basic Econometrics.McGraw Hill, New York, NY.

Hahn, R., \& Kuhnen, M. (2013). Determinants of sustainability reporting: a review of results, trends, theory, and opportunities in an expanding field of research. Journal of Cleaner Production, 59, 5-21.

Hair, J.F., Anderson R.E. Jr., Tatham, R.L. \& Black, W.C. (1995). Multivariate data analysis. Macmillan Publishing Company, New York,NYHaniffa, R. M., \& Cooke, T. E. (2005). The impact of culture and governance on corporate social reporting. Journal of Accounting and Public Policy, 24(5), 392-430.

Hart, S.G. (1994, August). Does it Pay to be Green. Paper Presented at the national meetings of the Academy of Management, Dallas,TX.

Hawken, P. (1993). The Ecology of Commerce: A Declaration of Sustainability. New York, NY: Harper Collins Publishers.

Huafang, X., \& Jianguo, Y. (2007). Ownership structure, board composition and corporate voluntary disclosure: evidence from listed companies in China. Managerial Auditing Journal, 22(6), 604-619.

Ikram, A., Su, Q., Fiaz, M., \& Shabbir, M. W. (2016). Cultural diversity and challenges for female entrepreneurs: Empirical Study of an emerging economy. World Academy of Science, Engineering and Technology, International Journal of Social, Behavioral, Educational, Economic, Business and Industrial Engineering, 10(10), 3012-3015

Islam, M.A., \& Deegan, C. (2008). Motivations for an organization within a developing country to report social responsibility information. Accounting, Auditing and Accountability Journal, 21(6), 850-874.

Jensen, M.C., \& Meckling, W.H. (1976). Theory of the firm: managerial behavior, agency costs and ownership structure. Journal of Financial Economics, 3(4), 305-360.

Johnson, R.A., \& Greening, D.W. (1994). Relationships between corporate social performance, financial performance, and firm governance. Best Paper Proceedings of the Academy of Management, 314-8.

Kuasirikun, N., \& Sherer, M. (2004). Corporate social accounting disclosure in Thailand. Accounting, Auditing \& Accountability Journal, 17(4), 629-60.

Khan, H. (2010). The effect of corporate governance elements on corporate social responsibility (CSR) reporting: empirical evidence from private commercial banks of Bangladesh. International Journal of Law and Management, 5(2), 82-109.

Laksmana, I. (2008). Corporate board governance and voluntary disclosure of executive compensation practices. Contemporary Accounting Research, 25(4), 1147-1182.

Lipton, M., \& Lorsch, J. (1992). A modest proposal for improved corporate governance. Business Lawyer, 48(1), 59-77.

Newson, M., \& Deegan, C. (2002). Global expectations and their association with corporate social disclosure practices in Australia, Singapore, and South Korea. International Journal of Accounting, 37(2), 183-213.

Ntim, C. G., \& Soobaroyen, T. (2013). Black economic empowerment disclosures by South African listed corporations: The influence of ownership and board characteristics. Journal of Business Ethics, 116(1), 121-138.

Peng, C.Y., So, T.S., Stage, F.K., \& St. John, E.P. (2002). The use and interpretation of logistic regression in higher education journals: 1988-1999. Research in Higher Education, 4(3), 259-293.

Rasmussen, L. (1997). Earth Community Earth Ethics, Orbis Books. New York, NY: Maryknoll.

Riahi-Belkaoui, A. (1992). Executive compensation,organizational effectiveness,social performance and firm performance. $A n$ Empirical Investigation, 19(1), 25-38.

Roberts, R.W. (1992). Determinants of corporate social responsibility disclosure: an application of stakeholder theory. Accounting, Organizations and Society, 17(6), 595-612.

Simmons, J.M. (2016). An examination of determinants of corporate social responsibility disclosure strategies. Thriving in a New World Economy (pp. 289-292). Springer International Publishing.

Shihping, K.H \& Yang. C.L. (2014). Corporate social performance: why it matters? Case of Taiwan. Chinese Management Studies, 8(4), $704-716$

Talha, M., Christopher, B. \& Karthikeyani, J. (2016). Determinants of corporate social reporting in India. Business Challenges in the Changing Economic Landscape 1, 71-88.

Vafeas, N. (1999). Board meeting frequency and firm performance. Journal of Financial Economics, 53(1), 113-42.

Webb, E. (2004). An examination of socially responsible firms' board structure. Journal of Management and Governance, 8(3), 255-277.

Woodward, D. G., Edwards, P. \& Birkin, F. (1996). Organizational legitimacy and stakeholder information provision. British Journal of Management, 7(4), 329-347.

Yang, S. K.-L. (2014). Corporate social performance: why it matters? Case of Taiwan. Chinese Management Studies, 8(4), $704-$ 716.

Zhang, J. Q., Zhu, H., \& Ding, H. B. (2013). Board composition and corporate social responsibility:an empirical investigation in the post sarbanes-oxley era. Journal of Business Ethics, 114(3), 381-392.

Zhang, Y., Zhang, H., \& Seiler, M. J. (2015). Impact of information disclosure on prices, volume, and market volatility: An experimental approach. Journal of Behavioral Finance, 16(1), 12-19. 